\title{
FORMATION OF „KOON” SYSTEMS RELIABILITY ESTIMATED WITH ANALYTICAL AND SIMULATION CALCULATION METHODS
}

\section{ZAPEWNIENIE WYMAGANEJ NIEZAWODNOŚCI UKLADÓW TYPU „KZN” SZACOWANEJ ANALITYCZNYMI I SYMULACYJNYMI METODAMI OBLICZENIOWYMI}

\author{
Stanisław Młynarski ${ }^{1}$, Robert Pilch ${ }^{2}$, Maksymilian Smolnik ${ }^{3}$, \\ Jan Szybka ${ }^{4}$, Grzegorz Wiązania ${ }^{5}$ \\ ${ }^{1}$ Cracow University of Technology, ${ }^{2}$ AGH University of Science and Technology, \\ ${ }^{3}$ AGH University of Science and Technology, ${ }^{4}$ AGH University of Science and \\ Technology, ${ }^{5}$ AGH University of Science and Technology,

\begin{abstract}
The methods of reliability estimation applied in order to verify the reliability level of koon systems consisting of renewable objects are presented in the paper. Application of the selected methods allows one to quickly verify the reliability level and to set the number of redundant elements in the real technical systems.
\end{abstract}

Keywords: reliability, renewable objects, koon systems, reliability estimation methods

Streszczenie: $W$ artykule przedstawiono metody szacowania niezawodności stosowane do weryfikacji poziomu niezawodności układów typu kzn, składajacych się z odnawialnych obiektów, których niezawodność opisana jest rozkładami wyktadniczym, normalnym $i$ Weibulla, o założonych parametrach. Zastosowanie wybranych obliczeniowych metod symulacyjnych umożliwia szybka weryfikacje poziomu niezawodności i dobór liczby elementów rezerwowych $w$ rzeczywistych systemach transportowych.

Slowa kluczowe: niezawodność, obiekty odnawialne, układy typu kzn, metody szacowania niezawodności 
Formation of ,koon" systems reliability estimated with analytical and simulation... Zapewnienie wymaganej niezawodności układów typu , kzn” szacowanej...

\section{FORMATION OF „KOON” SYSTEMS RELIABILITY ESTIMATED WITH ANALYTICAL AND SIMULATION CALCULATION METHODS}

\section{Introduction}

The aim of the article is to present reliability estimation methods employed in the verification of reliability level of koon systems, that is systems composed of repairable objects, whose reliability is described by exponential, normal and Weibull distributions of stated parameters. The use of selected simulation methods enables fast verification of reliability level and selection of the number of redundant components in real-life engineered systems [4, 6, 7], which can constitute an important part at the initial stage of their design process (cf. $[3,5])$. These calculation methods include calculation analytical method with the use of Kolmogorov's differential equations in Markov processes and commercial simulation method in the BlockSim application. The authors also propose newly developed reliability assessment simulation methods using the principle of cumulative distribution function inversion TFR (Times to Failures and Repairs) and CTS (Constant Time Step), in which reliability calculations for koon structures for any number of redundant objects and selected probability distributions of their operation are performed.

The correctness of the results obtained with the aforementioned methods was verified on some examples and the results proved satisfactory within errors acceptable in engineered systems used in real-life conditions.

The objective of the paper is to demonstrate the possibility of employing simulation calculation methods in defining the reserve level (the number of reserve engineered objects) in transportation systems ensuring the required reliability level in systems of threshold structures of koon type [8]. In the examples studied one, two and three reserve objects out of fifty objects in operation were adopted.

\section{Characteristics of calculation methods employed}

The assessment of reliability of systems composed of homogeneous repairable technical objects can be done by various methods. In particular, these methods can employ analytical relationships or be based on simulation. In practice, for the class of systems mentioned methods including the use of Markov processes to describe the time-dependent changes of system states can be applied. The application of the tool, i.e. Markov processes, requires the introduction of some assumptions related to:

- definition of time to failure of individual objects of the system only by means of exponential distribution function

- limitation of the number of objects that can make up the system in question due to the difficulties in running calculations for a large number of objects when the graph of transitions between states is plotted manually and Kolmogorov's differential equations written. 
For a system of koon structure and composed of identical and repairable objects a generalised graph of transitions between states in Markov process can be presented as in figure 1 . The failure rate of objects in the operation state was denoted with $\lambda$, in the state of reserve $\lambda_{r}$ and repair rate with $\mu$. When the reserve is hot $\lambda_{r}=\lambda$.

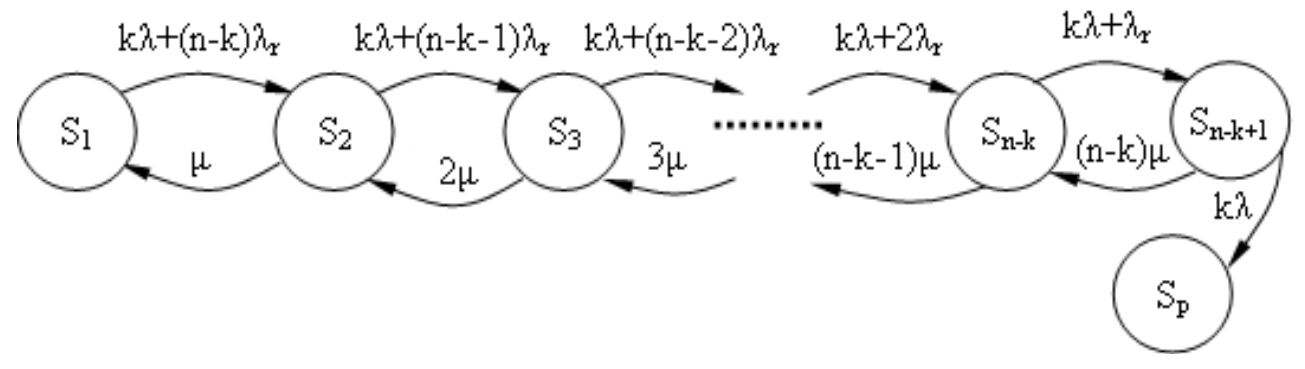

Fig. 1 Generalised graph of transition between states of a koon system with homogeneous objects

The number of availability states in which a koon system can be found is always larger by 1 than the difference between $n$ and $k$, that is larger by 1 than the number of reserve objects. Consequently, the presented model can be useful in reliability evaluation enabling ease of writing and solving Kolmogorov's differential equations for many real-life cases when the number of objects of an engineered system can amount to several tens or even hundreds while the number of reserve objects usually amounts to but a few. Moreover, owing to its analytical character, the model can be employed in the verification of the correctness and calculation accuracy of simulation methods.

Simulation models are developed for the reliability assessment of koon repairable systems when the objects are homogeneous and their time to failure is described by probability distribution other than exponential, which is presented further on in the paper.

In the calculations, apart from the aforementioned analytical method (denoted as IV), three simulation methods were used: TFR (denoted as III), CTS (denoted as II) and simulation in BlockSim (denoted as I).

TFR calculation method employs a well-known method of cumulative distribution function inversion and is based on the principle of sampling of objects' failure time and their repair termination time. The sampling of the failure time of an $i$-th object $\left(t_{u i}\right)$ is performed by using the pseudo-random number generator by the inversion of the object's time to failure cumulative distribution function: $t_{u i}=\mathrm{F}_{\mathrm{ui}}{ }^{-1}$ (rand). The same holds for its repair time: $t_{o i}=\mathrm{F}_{\mathrm{oi}}{ }^{-1}$ (rand). The subsequent values of time obtained in this way are added until the total value of time $(t)$ reaches the adopted time horizon $T_{h}$. The procedure is performed separately for all objects in the system and reserve objects respectively to their time to failure and repair distributions. 
Formation of , koon" systems reliability estimated with analytical and simulation... Zapewnienie wymaganej niezawodności układów typu , kzn” szacowanej...

Next, on the basis of the collected values of times for all the objects an analysis is done in which it is assumed that any failed object is immediately replaced with one of the reserve objects if at least one of them is in the availability state. The aim of the analysis is to identify in the given time horizon the moment when the number of objects $n-k+1$ is simultaneously in the failure state (in repair). If this happens, at the moment it occurred in the simulation procedure the whole system fails and the value of this time is stored. If such a situation does not take place, the simulation is successful. After the simulation has been repeated the boundary number of times $\left(n_{g r}\right)$, the system reliability is derived after formula: $R_{u}(t)=1-\left(n_{u}(t) / n_{g r}\right)$, where $n_{u}(t)$ is the number of simulations that ended in system failure that occurred until time $t$, and $n_{g r}$ is the number of simulations performed.

To determine the reliability characteristics of engineered systems of koon structure, composed of repairable elements a computer program based on stochastic simulations was developed. Its main advantage is the possibility of application of various probability distributions for the modelling of system components, which is different from the analytical method based on Markov processes, where only exponential distribution can be used. The program also enables an analysis of systems composed of non-homogeneous elements, i.e. systems whose components differ in reliability characteristics. Redundant objects can be defined as loaded (hot) reserves, partly loaded reserves and unloaded (cold) reserves. The probability distribution of repairs is also included. The input data are probability distributions together with parameters, defined separately for states of working, reserve and repair. Each element of the system can have different, independent of other elements, sets of distributions for particular states, which enables the modelling of non-homogeneous systems. Moreover, the time horizon, time step and number of simulation runs should be specified. On the basis of these data the program determines the moments of the transition of the system to the absorbing state. The calculation model is scalable and allows program paralleling, owing to which simulations can be performed in distributed systems, reducing the time of waiting for results. Another functionality of the program is the possibility of simulating systems in which the components are entered into service in series at different times, which is a significant advantage and approximates the results to the service reality.

The comparison of calculation results obtained from the proposed program and the other methods did not reveal significant discrepancies, which allows its favourable assessment and confirms its applicability for the determination of reliability of koon systems.

The program can be further developed to include options existing in real life, such as:

- preventive maintenance of system's components

- alternative models of transition between the states of renewal and operation and the states of standby and operation

- partial renewals

- economic aspects. 
Another method for the determination of system's reliability employs the BlockSim program environment based on random numbers generator and of L'Ecuyer's algorithm as well as Bayes-Durham randomisation.

The use of simulation of failure-free time in the BlockSim environment requires the utilization of the Monte Carlo simulation. Used in the Reliasoft packet, the Monte Carlo simulation lies in generating random values of time to failure for a relevant probability distribution of each of the system's components. This method is a useful tool of the computation of the reliability indices especially for objects in which the repair processes are incorporated. In the computation procedure a pseudo-random numbers generator was employed to define the values of operation parameters necessary for calculating reliability indices. The formation of the so-called pseudo-reality out of the operation parameters enables the simulation of objects functioning in it and the optimization of servicing/maintenance process [9]. The Monte Carlo simulation method applied in the BlockSim and the random numbers generator after L'Ecuyer's algorithm together with Bayes-Durham randomisation enables a complex assessment of the state of the object on the basis of the simulation of its failures and repairs over a stated time interval $[1,2]$. The input data include simulation duration time expressed in units of operation done and the number of re-simulations.

\section{Evaluation of accuracy of results of simulation based calculations}

The data on the reliability of the systems discussed adopted for calculations are given in Table 1. The time to failure of an object in operation or in reserve is described by one of three distributions: exponential, Weibull or normal. The repair time is always described by exponential distribution. The probability density function for Weibull distribution was adopted after formula:

$$
f(t)=v \beta^{-v} t^{v-1} \exp \left[-\left(\frac{t}{\beta}\right)^{v}\right],
$$

where:

- $v$ - shape parameter,

- $\beta$ - scale parameter.

Table 1. Distribution parameters adopted for calculations

\begin{tabular}{|c|c|c|c|c|c|}
\hline $\begin{array}{l}\text { Distribution/ } \\
\text { State of object }\end{array}$ & \multicolumn{2}{|c|}{ Operation } & \multicolumn{2}{|c|}{ Reserve } & Repair \\
\hline Exponential & \multicolumn{2}{|c|}{$\lambda=1 / 240[1 /$ day $]$} & \multicolumn{2}{|c|}{$\lambda_{\mathrm{r}}=1 / 730[1 /$ day $]$} & \multirow{3}{*}{$\begin{array}{c}\mu=1 \\
{[1 / \text { day }]}\end{array}$} \\
\hline Weibull & $v=2,5$ & $\beta=183$ [days] & $v_{\mathrm{r}}=1,13$ & $\begin{array}{c}\beta_{\mathrm{r}}=360 \\
\text { [days] }\end{array}$ & \\
\hline Normal & $\begin{array}{l}\mathrm{m}=183 \\
\text { [days] }\end{array}$ & $\mathrm{s}=30$ [days] & $\begin{array}{c}\mathrm{m}_{\mathrm{r}}=360 \\
\text { [days] }\end{array}$ & $\begin{array}{l}\mathrm{s}_{\mathrm{r}}=60 \\
\text { [days] }\end{array}$ & \\
\hline
\end{tabular}


Formation of , koon" systems reliability estimated with analytical and simulation... Zapewnienie wymaganej niezawodności układów typu , kzn” szacowanej...

Figures 2, 3 and 4 illustrate examples of reliability function curves of a 50 out 53 system determined by methods discussed in section 2 of the paper.

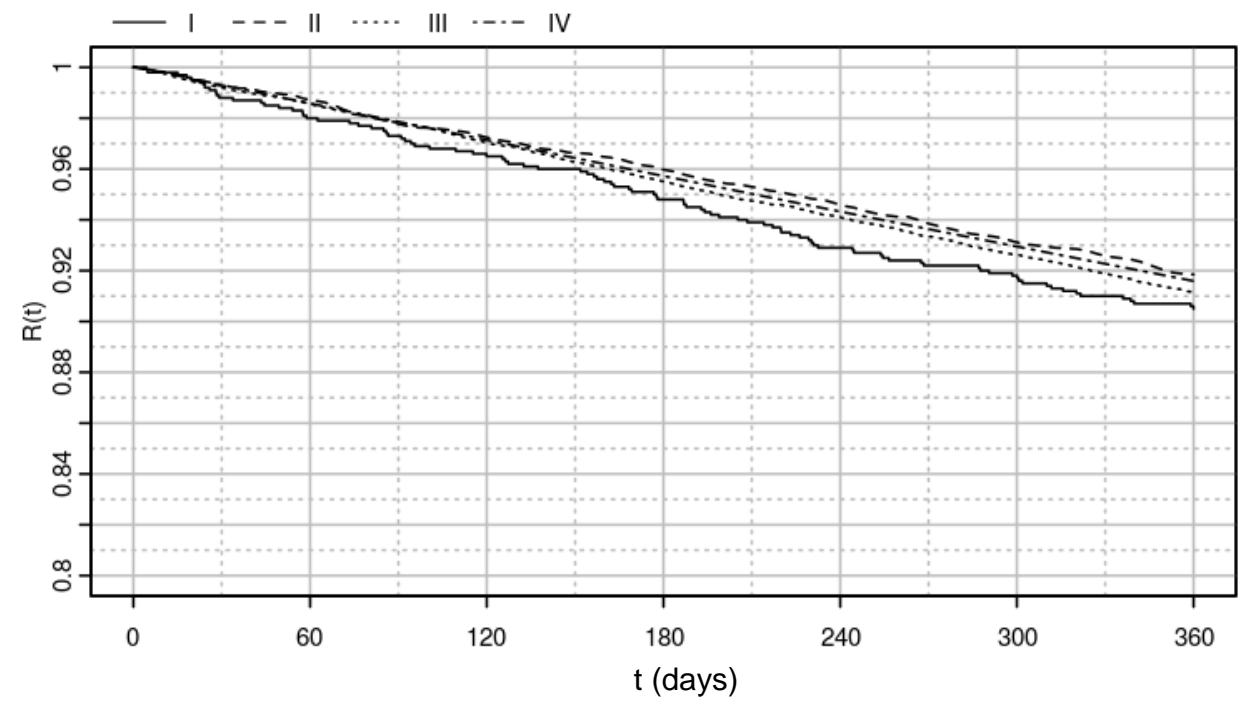

Fig. 2 Calculation results for a 50 out of 53 system, objects' operation time described by exponential distribution

The analysis of the reliability of a system with components of exponential distributions (Fig. 2), whose reliability was calculated by means of four methods, clearly shows that the differences between the results are very small indeed. In the analysed time horizon the maximum discrepancy for exponential distribution does not exceed $3 \%$.

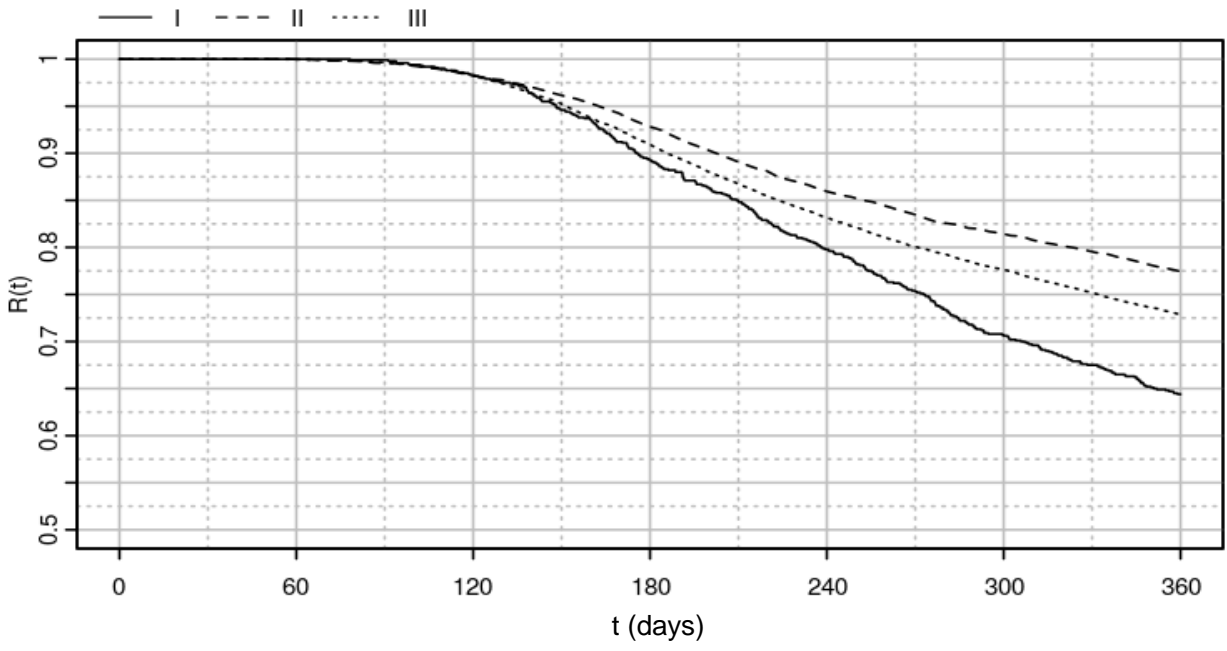

Fig. 3 Calculation results for a 50 out of 53 system, objects' operation time described by Weibull distribution 
For Weibull distribution the discrepancy between the obtained results, to the value of reliability of 0,95 , also does not exceed $3 \%$. In further time horizon the discrepancy increases due to the accumulation of the differences resulting from different simulation procedures.

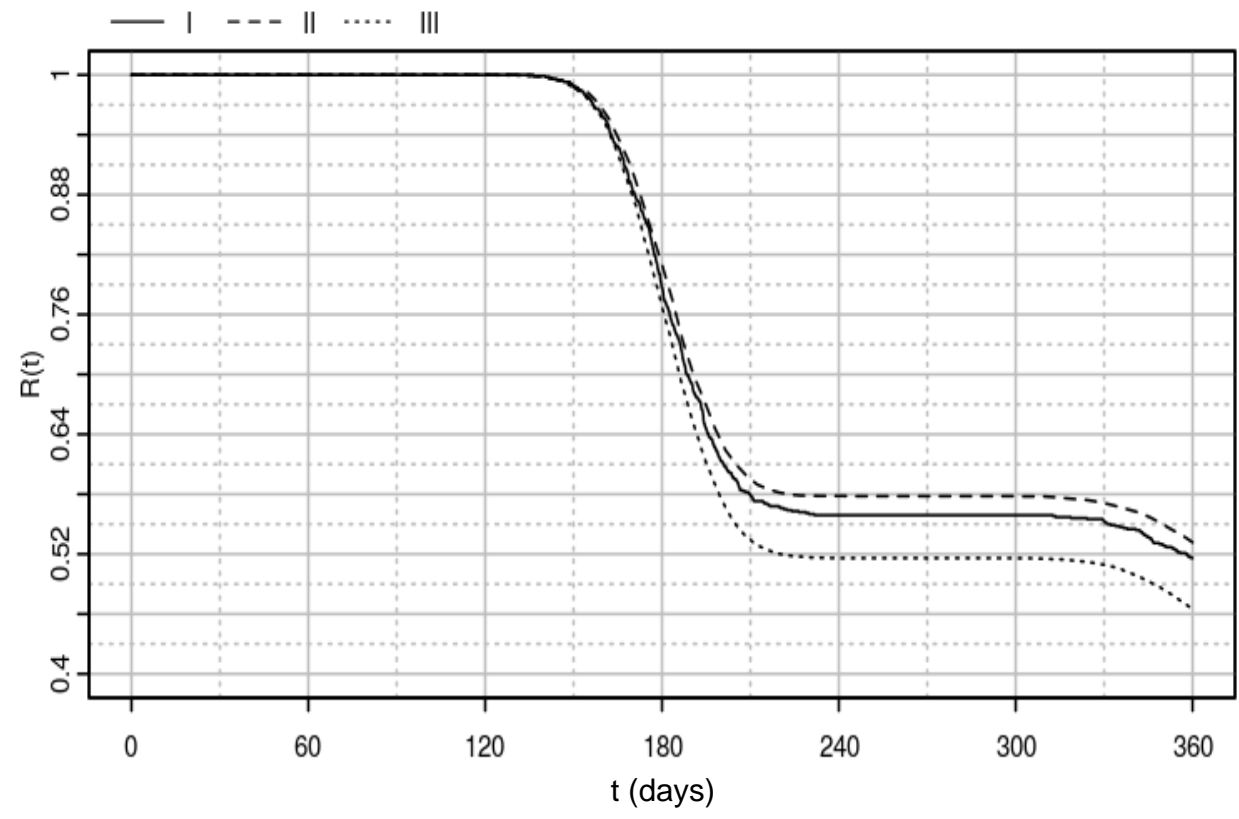

Fig. 4 Calculation results for a 50 out of 53 system, objects' operation time described by normal distribution

Also for the normal distribution to the reliability value of 0,95 the discrepancy between the results does not exceed 3\%. The characteristic change in the curves results from the fact that at a large number of brand new objects simultaneously introduced into operation causes an accumulation of failures in a short time interval. This phenomenon is repeated in subsequent periods of operation after repairs of the failed objects.

\section{Impact of reserve level on a koon system operation time until boundary allowable unreliability level}

The simulation based calculation results for 50 out of 51,50 out of 52 and 50 out of 53 systems are shown in plots in figure 5. They illustrate the reliability function curves of the analysed systems for exponential, Weibull and normal distributions describing the probability of the objects' correct operation. 
Formation of ,koon" systems reliability estimated with analytical and simulation... Zapewnienie wymaganej niezawodności układów typu , kzn” szacowanej...
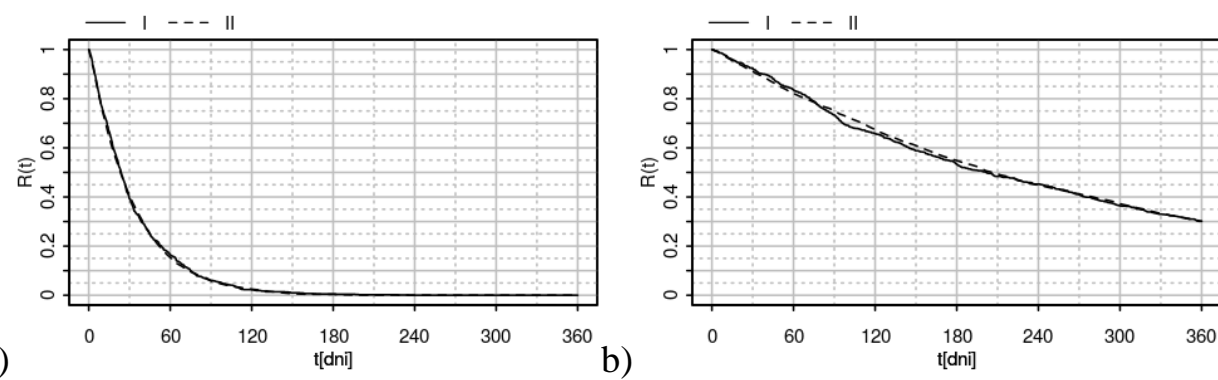

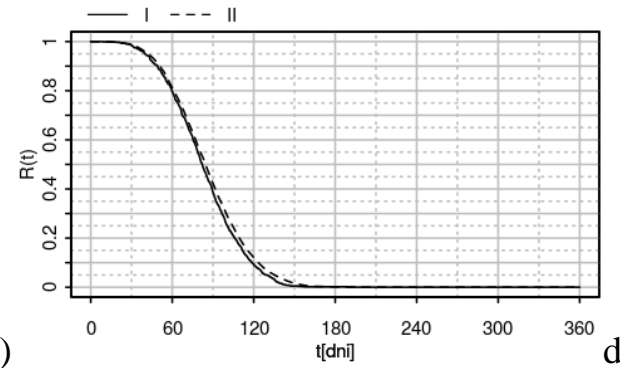

c)

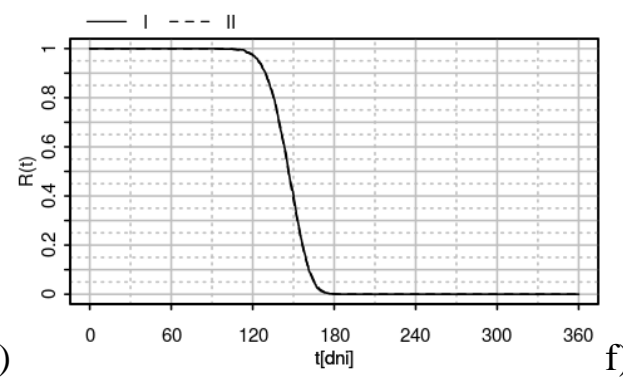

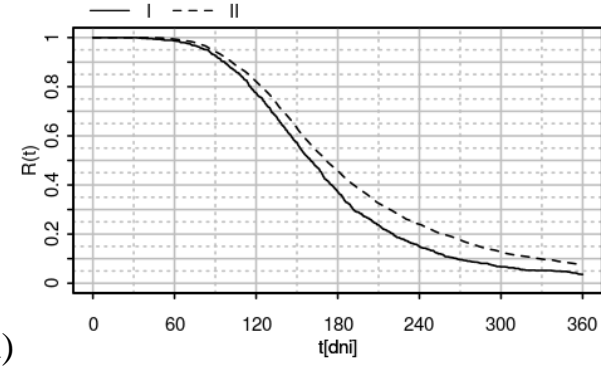

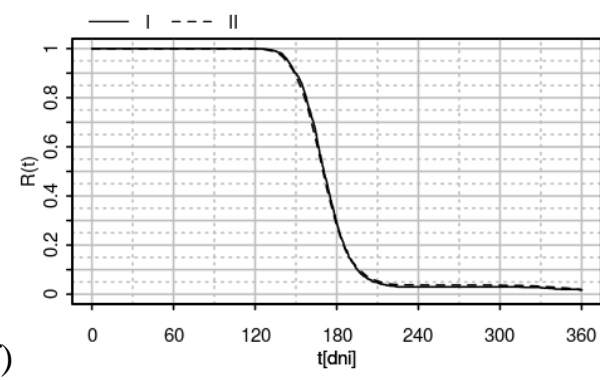

Fig. 5 Calculation results for systems: a), c), e) - 50 out of $51, b), d$ ), f) -50 out of $52, a)$ and $b)$ - objects' operation time described by exponential distribution, c) and d) - objects' operation time described by Weibull distribution, e) and f) objects' operation time described by normal distribution

It was assumed that the required reliability level of each system should be 0,95 . The systems' operation times until they reach the required reliability level depending on the objects' probability distributions differ considerably.

In the case of exponential distribution for a system with a single reserve component the reliability decreases very fast (Fig. 5a). This indicates that a single reserve is not sufficient. Increasing the number of reserve objects to three the operation time is increased to 175 days in the worst case (Fig. 2) for a system with the reliability level not less than 0,95 .

In the case of Weibull distribution for the required reliability level the operation time of a system with a single reserve object is about 40 days (Fig. 5c) and can be increased to about 150 days (Fig. 3) for three reserve objects.

For normal distribution the adopted required reliability level is maintained for about 130 days for a system with a single reserve object (Fig.) and about 140 days for a system with two reserve objects (Fig. 5f) and about 160 days when three reserve objects are entered (Fig. 4). 


\section{Conclusions}

Structural redundancy is of particular significance in transportation. The proposed simulation methods enable specification of the required number of reserve objects that ensure the implementation of transportation tasks at a required reliability level. The selection of the number of reserve components that ensure the correct operation of complex repairable technical systems, e.g. transport bases, requires the use of calculation methods. Such methods enable the assessment of reliability for any probability distributions of the correct operation of objects that function in koon systems.

The usability of some calculation methods has been verified by way of comparison of results of calculations performed on selected cases. Additionally, selected calculation results have been checked against the results obtained analytically, as for Markov processes.

The calculation results confirm the applicability of the proposed simulation methods which despite the adopted simplifications yield good results for various probability distributions. The analytical methods employed in the calculations of koon systems have some limitations that make them difficult to use in practice. These limitations are related to the number of reserve objects making up the analysed systems because an increase of the number of reserve objects significantly complicates the calculations. The simulation methods are free of such limitations. In practical applications, the specification of the number of reserve objects is particularly important in transport bases with a large number of vehicles including several tens of units, while maintaining the continuity of objectives is a priority.

\section{References}

[1] Johnson Paul E.: Monte Carlo Analysis in Academic Research. The Oxford Handbook of Quantitative Methods in Psychology, Vol. 1. 2013.

[2] Manzini R., Regattieri A., Pham H., Ferrari E.: Maintenance for Industrial Systems. Springer-VerlagGmbh. 2010.

[3] Młynarski S., Oprzędkiewicz J.: Systemowe rozwiązania zapewnienia bezpieczeństwa i niezawodności obiektów technicznych. Problemy Eksploatacji. Maint. Problems. 2012; 3: 39-54.

[4] Młynarski S., Pilch R., Smolnik M., Szkoda M., Szybka J.: Evaluation of the Safety Integrity Level (SIL) Due to the Guidelines of EN 61508 and with the Use of Markov Processes. Journal of KONBiN. 2015; 3: 73-84.

[5] Młynarski S., Pilch R., Smolnik M., Szybka J.: Kształtowanie układów technicznych w aspekcie zapewnienia ich niezawodnego i bezpiecznego funkcjonowania. Logistyka. 2015; 6: 1210-1218.

[6] Pilch R.: A method for obtaining the required system reliability level by applying preventive maintenance. Simulation. 2015; 97 (7): 615-624.

[7] Pilch R.: Extending the Possibilities of Quantitative Determination of SIL a Procedure Based on IEC 61508 and the Markov Model with Common Cause Failures. Qual. Reliab. Engng. Int. 2017; 33: 337-346.

[8] Szybka J.: Methodology for reliability estimation of system with sliding reserve. Scientific problems of machines operation and maintenance. 2010; 45 (163): 65-73.

[9] System Analysis Reference. Reliability, Availability \& Optimization. BlockSim 7. Reliasoft Corporation. Tucson AZ. USA. 1999-2007. 
Formation of , koon" systems reliability estimated with analytical and simulation... Zapewnienie wymaganej niezawodności układów typu , kzn” szacowanej...

\section{ZAPEWNIENIE WYMAGANEJ NIEZAWODNOŚCI UKŁADÓW TYPU „KZN" SZACOWANEJ ANALITYCZNYMI I SYMULACYJNYMI METODAMI OBLICZENIOWYMI}

\section{Wstęp}

W artykule przedstawiono metody szacowania niezawodności stosowane do weryfikacji poziomu niezawodności układów typu kzn, składających się z odnawialnych obiektów, których niezawodność opisana jest rozkładami wykładniczym, normalnym i Weibulla, o założonych parametrach. Zastosowanie wybranych obliczeniowych metod symulacyjnych umożliwia szybką weryfikację poziomu niezawodności i dobór liczby elementów rezerwowych w rzeczywistych systemach technicznych [4, 6, 7], co może stanowić istotny element na początkowym etapie procesu ich projektowania (por. [3, 5]). Te metody obliczeniowe to: analityczna metoda obliczeniowa $\mathrm{z}$ wykorzystaniem równań różniczkowych Kołmogorowa dla procesów Markowa, komercyjna metoda symulacyjna $\mathrm{w}$ aplikacji BlockSim oraz autorskie opracowania symulacyjnych metod oceny niezawodności z zastosowaniem zasady odwracania dystrybuanty TFR (Times to Failures and Repairs) i symulacyjnej metody obliczeniowej wyznaczania niezawodności CTS (Constant Time Step), realizującej obliczenia niezawodnościowe dla struktur typu kzn, dla dowolnej liczby obiektów rezerwowych i wybranych rozkładów prawdopodobieństwa ich poprawnej pracy.

Poprawność uzyskiwanych wyników obliczeń wyżej wymienionymi metodami zweryfikowano na wybranych przykładach i otrzymano zadawalające wyniki, $\mathrm{w}$ granicach błędów możliwych do zaakceptowania w systemach technicznych eksploatowanych w warunkach rzeczywistych.

Celem opracowania jest wykazanie możliwości zastosowania symulacyjnych metod obliczeniowych do kształtowania poziomu rezerwowania (liczby rezerwowych obiektów technicznych) W systemach transportowych, gwarantujących wymagany poziom niezawodności w układach o strukturach progowych typ kzn [8]. W rozpatrywanych przykładach przyjęto jeden, dwa i trzy obiekty rezerwowe przypadające na pięćdziesiąt obiektów pracujących.

\section{Charakterystyka zastosowanych metod obliczeniowych}

Szacowanie niezawodności układów składających się $\mathrm{z}$ jednorodnych odnawialnych obiektów technicznych prowadzone może być różnymi metodami. W szczególności mogą to być metody, w których wykorzystywane są zależności analityczne, albo metody oparte o symulacje. W praktyce, dla wymienionej klasy układów stosowane mogą być metody obejmujące wykorzystanie procesów Markowa w celu opisu zmian stanów systemu dokonujących się w czasie. 
Zastosowanie narzędzia, jakim są procesy Markowa wymaga jednak wprowadzenia założeń dotyczących:

- opisu czasu pracy do uszkodzenia poszczególnych obiektów układu wyłącznie za pomocą wykładniczego rozkładu prawdopodobieństwa,

- ograniczenia liczby obiektów, z których może składać się rozpatrywany układ, ze względu na trudności związane z prowadzeniem obliczeń dla dużej liczby obiektów przy ręcznym wykreślaniu grafu przejść pomiędzy stanami i zapisywaniu równań różniczkowych Kołmogorowa.

W przypadku, gdy układ posiada strukturę typu kzn i składa się z jednorodnych i odnawialnych obiektów, uogólniony graf przejść między stanami $\mathrm{w}$ procesie Markowa można przedstawić jak na rysunku 1. Intensywność uszkodzeń obiektów w stanie pracy oznaczono jako $\lambda$, w stanie rezerwy $\lambda_{r}$ a intensywność odnowy jako $\mu$. Dla przypadków gdy rezerwa jest rezerwą gorącą $\lambda_{r}=\lambda$.

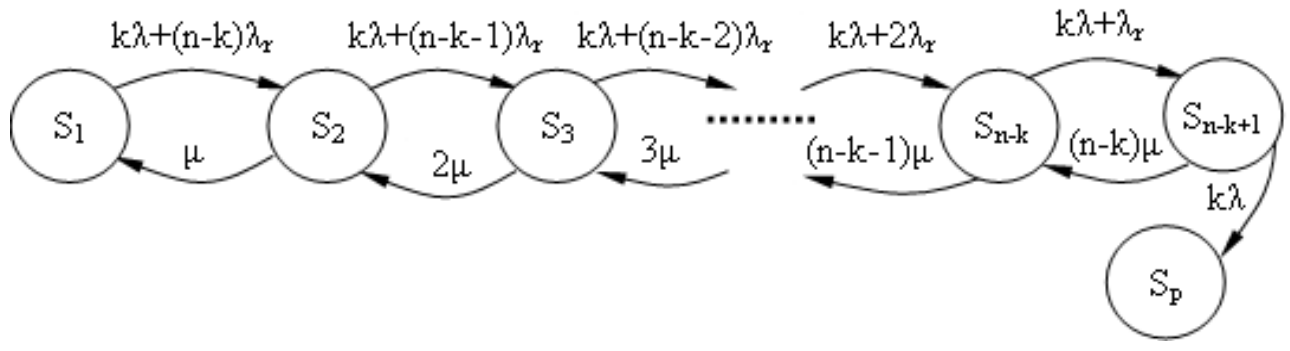

\section{Rys. 1 Uogólniony graf przejść między stanami układu kzn z jednorodnymi} obiektami

Liczba stanów zdatności w jakich może przebywać układ kzn jest zawsze o 1 większa od różnicy między wartościami $n$ i $k$, czyli o 1 większa od liczby obiektów rezerwowych. Stąd przedstawiony model może być użyteczny w ocenie niezawodności, umożliwiając łatwe zapisanie i rozwiązanie równań różniczkowych Kołmogorowa, dla wielu występujących w praktyce przypadków, gdzie liczba obiektów układu technicznego może wynosić kilkadziesiąt czy nawet kilkaset ale przy zazwyczaj tylko kilku obiektach rezerwowych. Ponadto ze względu na swój analityczny charakter model ten może być wykorzystany do weryfikacji poprawności i dokładności obliczeniowej metod symulacyjnych.

Modele symulacyjne budowane są w celu szacowania niezawodności odnawialnych układów kzn w przypadkach, gdy obiekty nie są jednorodne a czasy ich pracy do uszkodzenia opisywane są za pomocą innych niż wykładniczy rozkładów prawdopodobieństwa, co przedstawiono w dalszej części opracowania. Do obliczeń, obok ww. metody analitycznej (oznaczanej IV), zastosowano trzy metody symulacyjne: metodę obliczeniową TFR (oznaczaną III), metodę obliczeniową CTS (oznaczaną II) oraz metodę symulacyjną w aplikacji BlockSim (oznaczaną I). 
Formation of ,koon" systems reliability estimated with analytical and simulation... Zapewnienie wymaganej niezawodności układów typu , kzn” szacowanej...

Metoda obliczeniowa TFR wykorzystująca znaną metodę odwracania dystrybuanty oparta jest na zasadzie losowania chwil wystąpienia uszkodzeń obiektów oraz chwil zakończenia ich odnowy. Losowanie chwili, w której wystąpi uszkodzenie $i$-tego obiektu $\left(t_{u i}\right)$ dokonywane jest przy wykorzystaniu generatora liczb pseudolosowych na zasadzie odwrócenia dystrybuanty czasu pracy do uszkodzenia tego obiektu: $t_{u i}=\mathrm{F}_{\mathrm{ui}}{ }^{-1}($ rand) . Na tej samej zasadzie losowana jest chwila zakończenia jego odnowy: $t_{o i}=\mathrm{F}_{\mathrm{oi}}{ }^{-1}$ (rand). Otrzymane $\mathrm{w}$ ten sposób kolejne wartości czasu są do siebie dodawane aż sumaryczna wartość czasu $(t)$ osiągnie przyjęty horyzont czasowy $T_{h}$. Procedura ta jest wykonywana niezależnie dla wszystkich obiektów $\mathrm{w}$ układzie oraz obiektów rezerwowych zgodnie $\mathrm{z}$ odpowiednimi dla nich rozkładami czasu pracy do uszkodzenia i odnowy. Następnie na podstawie zgromadzonych wartości czasów dla wszystkich obiektów dokonywana jest analiza, w której zakłada się, że dowolny uszkodzony obiekt jest natychmiast zastępowany przez jeden $\mathrm{z}$ obiektów rezerwowych o ile przynajmniej jeden z nich jest w stanie zdatności. Prowadzona analiza ma na celu znalezienie w rozpatrywanym horyzoncie czasowym chwili, w której jednocześnie w stanie niezdatności (w odnowie) znajdzie się liczba obiektów $n-k+1$. Jeśli taka sytuacja zaistniała, to $\mathrm{w}$ chwili gdy wystąpiła, w procedurze symulacji następuje uszkodzenie całego układu a wartość tego czasu jest zapamiętywana. Jeśli taka sytuacja nie wystąpiła symulacja zakończyła się sukcesem. Po powtórzeniu symulacji przyjętą graniczną liczbę razy $\left(n_{g r}\right)$ niezawodność układu wyznacza się wg zależności: $R_{u}(t)=1-\left(n_{u}(t) / n_{g r}\right)$, gdzie $n_{u}(t)$ jest liczbą symulacji zakończonych uszkodzeniem układu, które nastąpiło do chwili $t$, a $n_{g r}$ jest liczbą przeprowadzonych symulacji.

W celu wyznaczania charakterystyk niezawodnościowych układów technicznych o strukturze nadmiarowej typu kzn, złożonych $\mathrm{z}$ elementów odnawialnych opracowano program komputerowy bazujący na symulacjach stochastycznych. Jego główną zaletą jest możliwość stosowania różnych rozkładów prawdopodobieństwa do modelowania elementów układu w odróżnieniu od analitycznej metody opartej na procesach Markowa, gdzie możliwe jest jedynie wykorzystanie rozkładu wykładniczego. Dodatkowo pozwala na analizę układów złożonych z elementów niejednorodnych, czyli takich, w których elementy układu różnią się od siebie pod względem charakterystyk niezawodnościowych. Istnieje możliwość definiowania rezerw jako gorące, ciepłe i zimne. Uwzględniony jest również rozkład prawdopodobieństwa odnów. Danymi wejściowymi do programu są rozkłady prawdopodobieństwa wraz z parametrami, definiowane odrębnie dla stanów pracy, rezerwy i odnowy. Każdy element układu może mieć różne, niezależne od innych elementów, zestawy rozkładów dla poszczególnych stanów, co daje możliwość modelowania układów niejednorodnych. Należy również określić horyzont czasowy, wartość kroku czasowego i liczbę przebiegów symulacji. Na podstawie tych danych program wyznacza chwile przejścia układu do stanu pochłaniania. 
Przyjęty model obliczeniowy jest skalowalny i pozwala na zrównoleglenie programu, co daje możliwość prowadzenia symulacji w systemach rozproszonych zmniejszając tym samym czas oczekiwania na wyniki.

Dodatkową funkcjonalnością programu jest możliwość symulowania układów, w których elementy są wprowadzane do eksploatacji seriami w różnych chwilach czasowych, co jest istotną zaletą i przybliża wyznaczone wyniki do rzeczywistości eksploatacyjnej.

Porównanie wyników obliczeń uzyskanych $\mathrm{z}$ opracowanego programu i pozostałych omawianych metod nie wykazały znaczących rozbieżności. Pozwala to na jego pozytywną oceną i potwierdza jego przydatność do wyznaczania niezawodności układów typu kzn.

Istnieje możliwość rozbudowy programu o dodatkowe możliwości, występujące w rzeczywistych układach, takie jak:

- odnowy profilaktyczne elementów układu,

- alternatywne modele przejścia pomiędzy stanami odnowy i pracy oraz rezerwy i pracy,

- odnowy częściowe,

- aspekty ekonomiczne.

Kolejna metoda dotyczy wyznaczania niezawodności systemu przy wykorzystaniu środowiska programowego BlockSim opartego o generator liczb losowych i algorytm Ecuyer'a oraz losowanie Baysa-Durhama.

Korzystanie $\mathrm{z}$ metody symulacyjnej czasu poprawnej pracy $\mathrm{w}$ środowisku BlockSim wymaga zastosowania symulacji Monte Carlo, która zastosowana w pakiecie oprogramowania firmy Reliasoft polega na generowaniu losowych wartości czasu do uszkodzenia dla odpowiedniego rozkładu prawdopodobieństwa, każdego z elementów systemu. Metoda Monte Carlo jest przydatną techniką obliczania wartości wskaźników niezawodności szczególnie dla obiektów, w których uwzględniane są procesy odnowy. W procedurze obliczeniowej zastosowano generator liczb pseudo-losowych w celu wyznaczenia wartości parametrów eksploatacyjnych potrzebnych do obliczenia wskaźników niezawodności. Wytworzenie $\mathrm{z}$ wybranych parametrów eksploatacyjnych tak zwanej pseudo-rzeczywistości umożliwia symulację funkcjonowania w niej obiektów oraz optymalizację procesu obsługowego [9]. Stosowana w programie BlockSim metoda symulacji Monte Carlo i stosowany w niej generator liczb losowych wg algorytmu L'Ecuyer i losowaniu Bays Durham, umożliwia kompleksową ocenę stanu obiektu na podstawie symulacji uszkodzeń i napraw obiektu w zadanym przedziale czasu [1, 2]. Do wprowadzanych danych wejściowych należą przede wszystkim czas trwania symulacji, wyrażony w przyjętych jednostkach wykonywanej pracy oraz liczba powtórzeń symulacji. 
Formation of , koon" systems reliability estimated with analytical and simulation... Zapewnienie wymaganej niezawodności układów typu , kzn” szacowanej...

\section{Ocena dokładności wyników obliczeń przeprowadzonych metodami symulacyjnymi}

W tabeli 1 zestawiono przyjęte do obliczeń dane o niezawodności rozpatrywanych układów. Czas pracy do uszkodzenia obiektu normalnie pracującego albo rezerwowego opisywany jest jednym z trzech rozkładów: wykładniczym, Weibulla albo normalnym. Czas przebywania w odnowie zawsze opisywany jest rozkładem wykładniczym. Funkcję gęstości prawdopodobieństwa dla rozkładu Weibulla przyjęto według zależności:

$$
f(t)=v \beta^{-v} t^{v-1} \exp \left[-\left(\frac{t}{\beta}\right)^{v}\right],
$$

gdzie:

$-v$ - parametr kształtu,

- $\beta$ - parametr skali.

Tabela 1. Wartości parametrów rozkładów przyjętych do obliczeń

\begin{tabular}{|c|c|c|c|c|c|}
\hline $\begin{array}{c}\text { Rozkład/ } \\
\text { Stan obiektu }\end{array}$ & \multicolumn{2}{|c|}{ Praca } & \multicolumn{2}{|c|}{ Rezerwa } & Odnowa \\
\hline Wykładniczy & \multicolumn{2}{|c|}{$\lambda=1 / 240$ [1/dzień] } & \multicolumn{2}{|c|}{$\lambda_{\mathrm{r}}=1 / 730$ [1/dzień] } & \multirow{3}{*}{$\begin{array}{c}\mu=1 \\
{[1 / \text { dzień }]}\end{array}$} \\
\hline Weibulla & $v=2,5$ & $\beta=183$ [dni] & $v_{\mathrm{r}}=1,13$ & $\begin{array}{c}\beta_{\mathrm{r}}=360 \\
{[\mathrm{dni}]}\end{array}$ & \\
\hline Normalny & $\begin{array}{c}\mathrm{m}=183 \\
{[\mathrm{dni}]}\end{array}$ & $\mathrm{s}=30[\mathrm{dni}]$ & $\begin{array}{c}\mathrm{m}_{\mathrm{r}}=360 \\
{[\mathrm{dni}]}\end{array}$ & $\mathrm{s}_{\mathrm{r}}=60$ [dni] & \\
\hline
\end{tabular}

Na rysunkach nr 2, 3 i 4 pokazano przykładowe przebiegi funkcji niezawodności układu 50 z 53 wyznaczone metodami przedstawionymi w rozdziale 2.

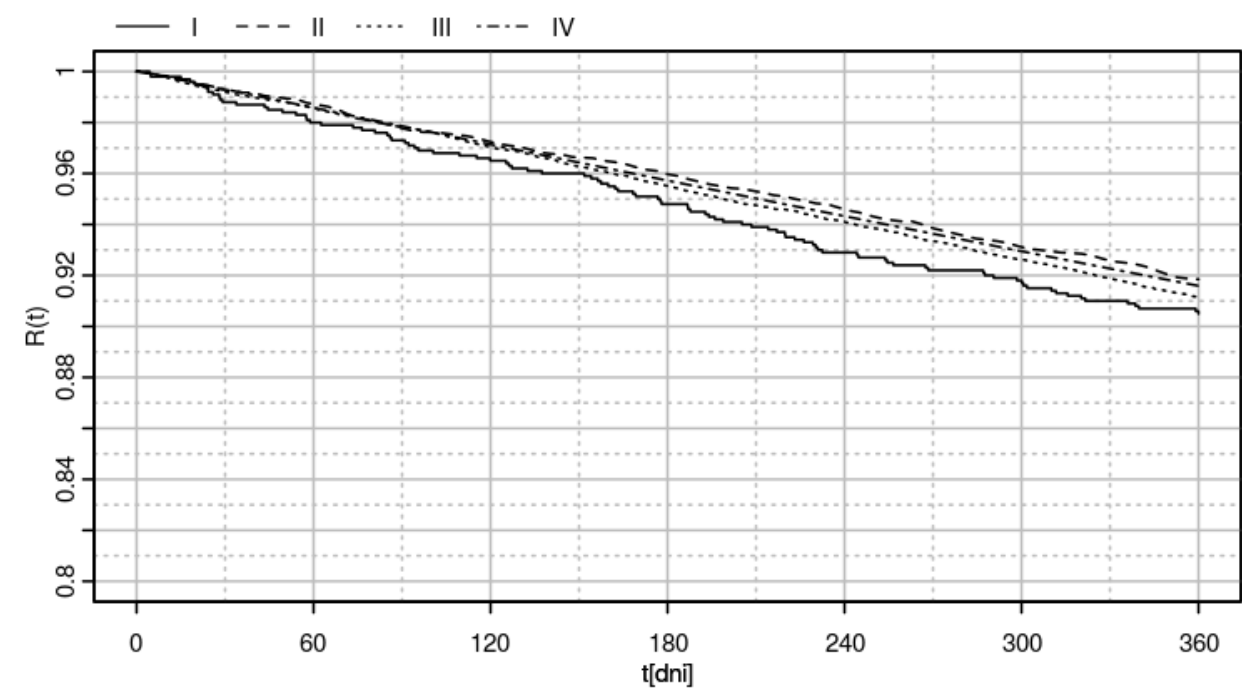

Rys. 2 Wyniki obliczeń dla układu 50 z 53, czas pracy obiektów opisywany rozktadem wyktadniczym 
Analizując przebieg niezawodności dla układu z elementami o rozkładach wykładniczych (rysunek 2), którego niezawodność obliczono czterema metodami wyraźnie widać, że otrzymano niewiele różniące się między sobą wyniki. $\mathrm{W}$ analizowanym horyzoncie czasowym maksymalna rozbieżność dla przypadku rozkładu wykładniczego nie przekroczyła wartości 3\%.

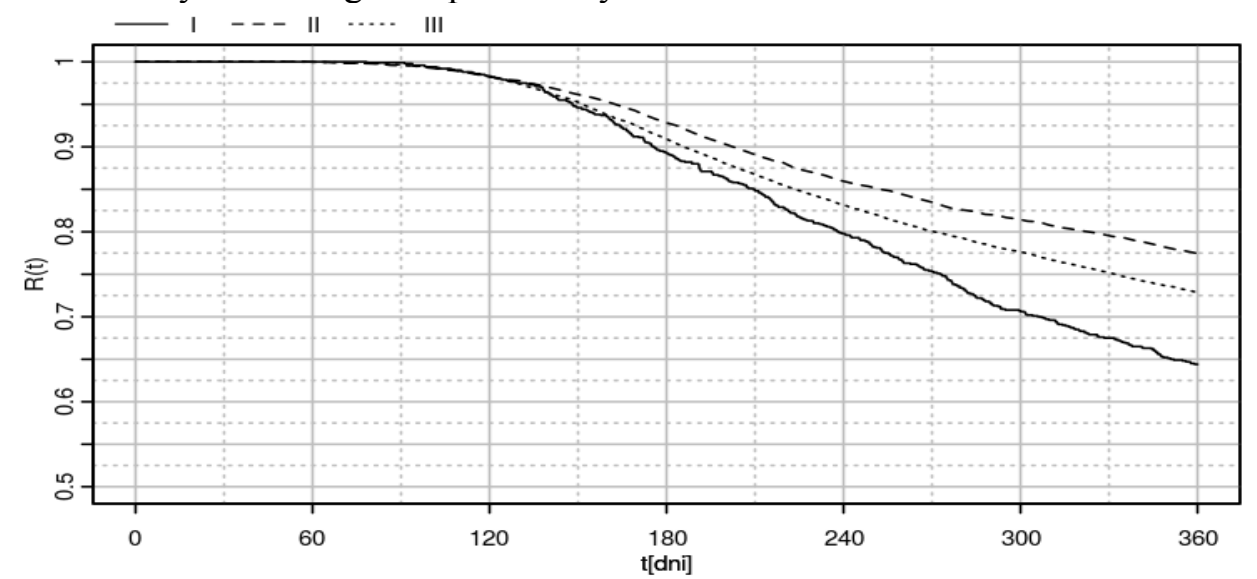

Rys. 3 Wyniki obliczeń dla układu 50 z 53, czas pracy obiektów opisywany rozkladem Weibulla

Dla rozkładu Wiebulla rozbieżność między uzyskanymi wynikami, do wartości niezawodności 0,95 , również nie przekracza $3 \%$. W dalszym horyzoncie czasowym rozbieżność sukcesywnie rośnie, na skutek kumulujących się różnic wynikających $\mathrm{z}$ odmiennych procedur symulacyjnych.

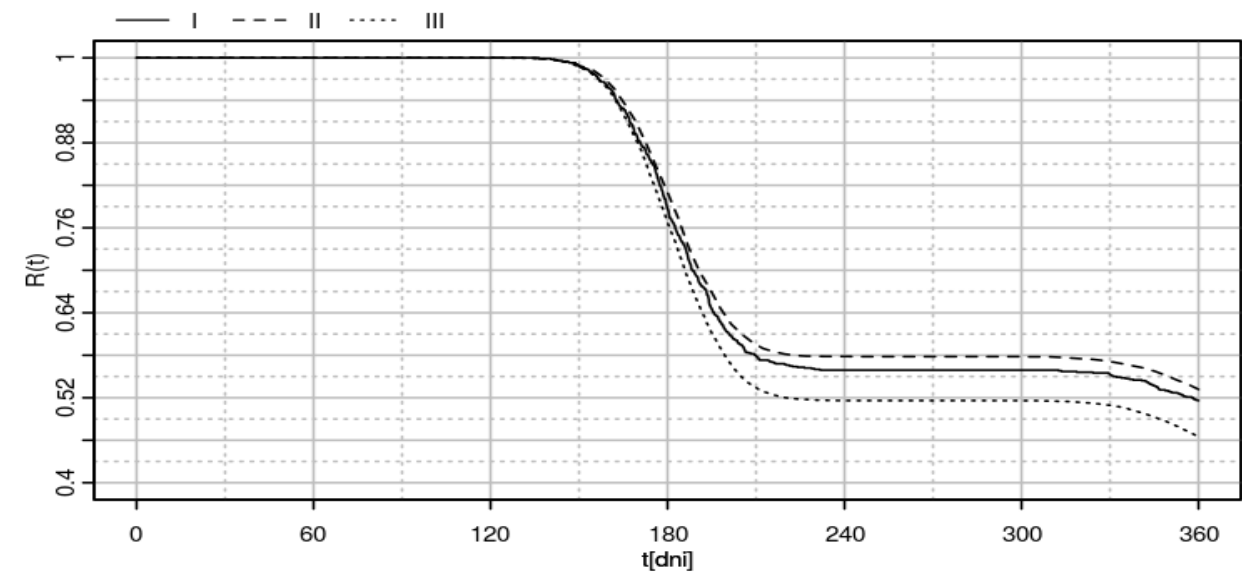

Rys. 4 Wyniki obliczeń dla układu 50 z 53, czas pracy obiektów opisywany rozkladem normalnym

Również w przypadku rozkładu normalnego do wartości niezawodności 0,95 rozbieżność między wynikami nie przekracza 3\%. Charakterystyczna zmiana przebiegu wykresu wynika z faktu że przy dużej liczbie obiektów pracujących od nowości następuje kumulacja uszkodzeń w krótkim przedziale czasu. 
Formation of , koon" systems reliability estimated with analytical and simulation... Zapewnienie wymaganej niezawodności układów typu , kzn” szacowanej...

Zjawisko to powtarza się w kolejnych okresach eksploatacji, po wykonaniu odnów uszkodzonych obiektów.

\section{Wpływ poziomu rezerwowania na czas pracy układu „kzn” do osiągnięcia granicznego dopuszczalnego poziomu niezawodności}

Wyniki obliczeń symulacyjnych dla układów 50 z 51, 50 z 52 i 50 z 53 zamieszczono na wykresach pokazanych na rysunku 5. Ilustrują one przebieg funkcji niezawodności badanych układów dla rozkładów wykładniczego, normalnego i Weibulla opisujących prawdopodobieństwo poprawnej pracy obiektów.

a)
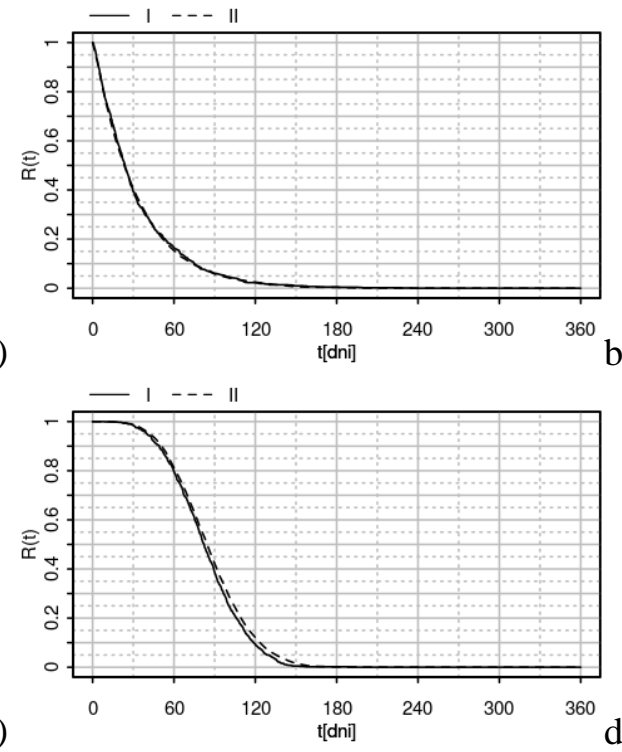

c)

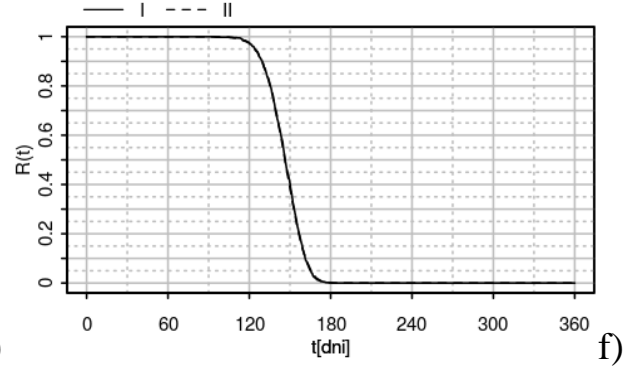

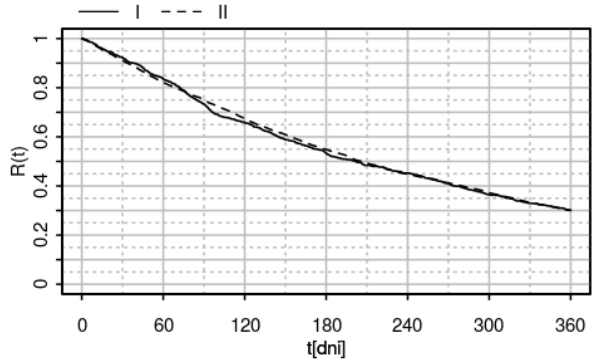

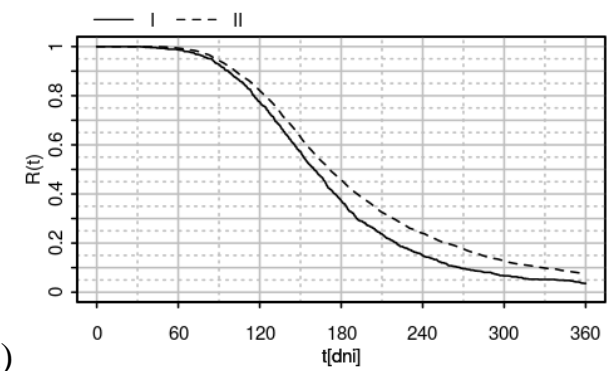

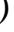

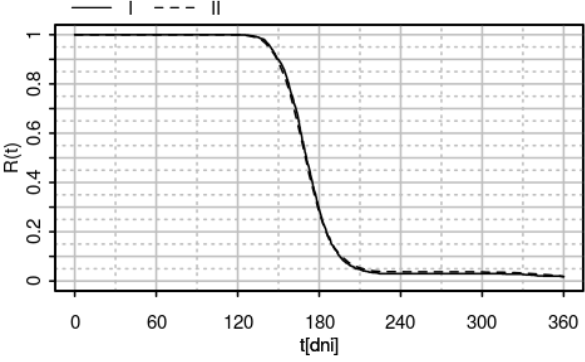

Rys. 5 Wyniki obliczeń dla uktadów: a), c), e) - 50 z 51, b), d), f) - 50 z 52, a) i b) - czas pracy obiektów opisywany rozktadem wyktadniczym, c) i d) - czas pracy obiektów opisywany rozktadem Weibulla, e) if) - czas pracy obiektów opisywany rozkładem normalnym

Założono, że wymagany poziom niezawodności każdego z układów powinien wynosić 0,95 . Czasy eksploatacji układów do osiągnięcia wymaganego poziomu niezawodności $\mathrm{w}$ zależności od rozkładów prawdopodobieństwa obiektów są znacznie zróżnicowane. 
W przypadku rozkładu wykładniczego dla układu z pojedynczym elementem rezerwowym niezawodność bardzo szybko maleje (rys. 5a) co oznacza, że pojedyncza rezerwa jest niewystarczająca. Zwiększając liczbę elementów rezerwowych do trzech uzyskujemy w najgorszym przypadku wydłużenie czasu pracy do 175 dni (rys. 2) dla układu z poziomem niezawodności nie mniejszym niż 0,95 .

W przypadku rozkładu Weibulla dla założonego poziomu niezawodności czas pracy układu z pojedynczym obiektem rezerwowym wynosi około 40 dni (rys. 5c) i można go zwiększyć do wartości około 150 dni (rys. 3) dla trzech obiektów rezerwowych.

Dla rozkładu normalnego przyjęty wymagany poziom niezawodności jest utrzymywany przez około 130 dni dla układu z pojedynczą rezerwą (rys. 5e) oraz przez około 140 dni dla układu z dwoma obiektami rezerwowymi (rys. 5f) i przez około 160 dni, gdy wprowadzone są trzy obiekty rezerwowe (rys. 4).

\section{Podsumowanie}

Rezerwowanie strukturalne ma szczególne znaczenie w transporcie. Zaproponowane metody symulacyjne umożliwiają wyznaczenie wymaganej liczby obiektów rezerwowych zapewniających realizację zadań transportowych na wymaganym poziomie niezawodności.

Dobór liczby elementów rezerwowych gwarantujących poprawną pracę złożonych odnawialnych układów technicznych, np. typu baz transportowych, wymaga zastosowania metod obliczeniowych, które umożliwiają szacowanie niezawodności dla dowolnych rozkładów prawdopodobieństwa poprawnej pracy badanych obiektów, funkcjonujących w układach typu kzn.

Zweryfikowano użyteczność wybranych metod obliczeniowych porównując uzyskane wyniki obliczeń przeprowadzonych na wybranych przykładach i dodatkowo sprawdzono wybrane rezultaty obliczeń z wynikami uzyskanymi na drodze analitycznej, stosowanej dla procesów Markowa.

Otrzymane wyniki obliczeń potwierdzają użyteczność proponowanych metod symulacyjnych, które pomimo przyjmowanych uproszczeń dają poprawne rezultaty dla różnych rozkładów prawdopodobieństwa. Metody analityczne stosowane do obliczeń układów typu kzn posiadają ograniczenia, które utrudniają zastosowanie ich w praktyce. Ograniczenia te dotyczą liczby obiektów występujących w badanych układach gdyż zwiększenie liczby obiektów rezerwowych znacznie komplikuje przeprowadzenie obliczeń. Tego typu ograniczenie nie występuje w metodach symulacyjnych. W praktyce, wyznaczenie liczby obiektów rezerwowych ma szczególne znaczenie w bazach transportowych, gdzie wy-stępuje duża liczba pojazdów obejmująca kilkadziesiąt jednostek, a utrzymanie ciągłości realizowanych zadań jest priorytetem.

\section{Literatura}

[1] Johnson Paul E.: Monte Carlo Analysis in Academic Research. The Oxford Handbook of Quantitative Methods in Psychology, Vol. 1. 2013.

[2] Manzini R., Regattieri A., Pham H., Ferrari E.: Maintenance for Industrial Systems. Springer-VerlagGmbh. 2010.

[3] Młynarski S., Oprzędkiewicz J.: Systemowe rozwiązania zapewnienia bezpieczeństwa i niezawodności obiektów technicznych. Problemy Eksploatacji. Maint. Problems. 2012; 3: 39-54. 
Formation of ,koon" systems reliability estimated with analytical and simulation... Zapewnienie wymaganej niezawodności układów typu , kzn” szacowanej...

[4] Młynarski S., Pilch R., Smolnik M., Szkoda M., Szybka J.: Evaluation of the Safety Integrity Level (SIL) Due to the Guidelines of EN 61508 and with the Use of Markov Processes. Journal of KONBiN. 2015; 3: 73-84.

[5] Młynarski S., Pilch R., Smolnik M., Szybka J.: Kształtowanie układów technicznych $\mathrm{w}$ aspekcie zapewnienia ich niezawodnego i bezpiecznego funkcjonowania. Logistyka. 2015; 6: 1210-1218.

[6] Pilch R.: A method for obtaining the required system reliability level by applying preventive maintenance. Simulation. 2015; 97 (7): 615-624.

[7] Pilch R.: Extending the Possibilities of Quantitative Determination of SIL a Procedure Based on IEC 61508 and the Markov Model with Common Cause Failures. Qual. Reliab. Engng. Int. 2017; 33: 337-346.

[8] Szybka J.: Methodology for reliability estimation of system with sliding reserve. Scientific problems of machines operation and maintenance. 2010; 45 (163): 65-73.

[9] System Analysis Reference. Reliability, Availability \& Optimization. BlockSim 7. Reliasoft Corporation. Tucson AZ. USA. 1999-2007.

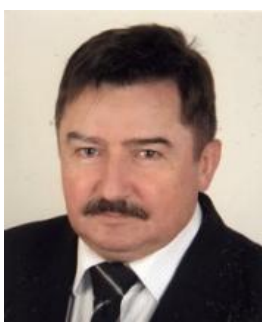

Dr inz. Stanistaw Mhynarski, absolwent Wydziatu Mechanicznego Politechniki Krakowskiej. Staż zawodowy w NY USA w Zakładach Mechaniki Precyzyjnej. Studia doktoranckie na Wydz. Mechanicznym PK $i$ uzyskanie stopnia doktora nauk technicznych. Od 1987r. pracownik naukowo-dydaktyczny PK na stanowisku adiunkta. Specjalność $i$ zainteresowania naukowe $w$ dziedzinie eksploatacji, niezawodności oraz bezpieczeństwa maszyn, pojazdów i systemów technicznych (Udziat 20\%).

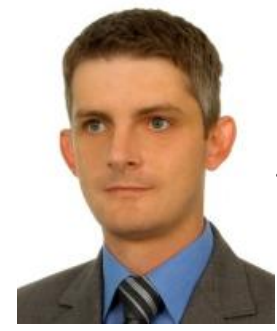

Dr inz. Robert Pilch, absolwent Wydziatu Inżynierii Mechanicznej i Robotyki AGH w Krakowie. Studia doktoranckie - WIMiR, AGH - uzyskanie stopnia doktora nauk technicznych. Od 2006: pracownik naukowo-dydaktyczny (adiunkt), WIMiR, AGH. Zainteresowania naukowe: niezawodność i eksploatacja maszyn, bezpieczeństwo systemów technicznych, niezawodność ukladów sieciowych, odnawianie profilaktyczne obiektów technicznych (Udziat 20\%).

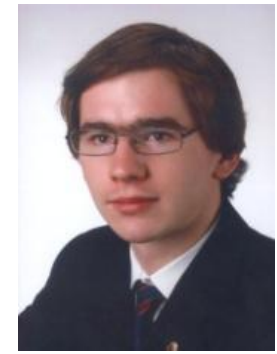

mgr inz.Maksymilian Smolnik, absolwent Wydziału Inżynierii Mechanicznej i Robotyki, AGH w Krakowie. Od 2013: Studia doktoranckie na WIMiR, AGH. Obecnie pracownik naukowodydaktyczny (asystent) WIMiR, AGH. Zainteresowania naukowe: budowa i eksploatacja maszyn - zwłaszcza pojazdów szynowych $i$ samochodowych, niezawodność systemów technicznych, metodologia projektowania systemów i procesów, Teoria rozwiazywania zadań wynalazczych-TRIZ (Udziat 15\%).

Jan Szybka (udziat 15\%)

Grzegorz Wiazania (Udział 30\%) 